University of Nebraska - Lincoln

DigitalCommons@University of Nebraska - Lincoln

Publications from USDA-ARS / UNL Faculty

U.S. Department of Agriculture: Agricultural

Research Service, Lincoln, Nebraska

August 1988

\title{
WINTER WHEAT GROWTH IN ARTIFICIALLY COMPACTED SOIL
}

Wallace Wilhelm

University of Nebraska-Lincoln, wwilhelm1@unl.edu

L. N. Mielke

USDA-ARS

Follow this and additional works at: https://digitalcommons.unl.edu/usdaarsfacpub

Part of the Agricultural Science Commons

Wilhelm, Wallace and Mielke, L. N., "WINTER WHEAT GROWTH IN ARTIFICIALLY COMPACTED SOIL" (1988). Publications from USDA-ARS / UNL Faculty. 100.

https://digitalcommons.unl.edu/usdaarsfacpub/100

This Article is brought to you for free and open access by the U.S. Department of Agriculture: Agricultural Research Service, Lincoln, Nebraska at DigitalCommons@University of Nebraska - Lincoln. It has been accepted for inclusion in Publications from USDA-ARS / UNL Faculty by an authorized administrator of DigitalCommons@University of Nebraska - Lincoln. 


\title{
WINTER WHEAT GROWTH IN ARTIFICIALLY COMPACTED SOIL
}

\author{
W. W. WILHELM and L. N. MIELKE \\ Agricultural Research Service, U. S. Department of Agriculture, University of Nebraska- \\ Lincoln, Lincoln, NE 68583-0915, U.S.A. Received 17 July 1987, accepted 29 Feb. \\ 1988.
}

Wilhelm, W. W. AND MielKe, L. N. 1988. Winter wheat growth in artificially compacted soil. Can. J. Soil Sci. 68: 527-535.

Dense soil tillage pans can develop from the improper use of tillage tools. The influence of compacted layers or pans on plant growth and development, although much studied, is not clearly understood. This greenhouse experiment evaluated the influence of uniformly compacted soil and thin layers of compacted soil placed at various depths on early growth of winter wheat (Triticum aestivum L.). Artificially compacted soil [Alliance silt loam, Aridic Argiustoll (Eluviated Brown Chernozem); A horizon] profiles were constructed in polyvinyl chloride tubes of $150-\mathrm{mm}$ diameter by $350 \mathrm{~mm}$ long. Treatments were: (1) uniformly noncompacted (bulk density $1.30 \mathrm{Mg} \mathrm{m}^{-3}$ ) soil; (2) uniformly compacted (bulk density $1.80 \mathrm{Mg} \mathrm{m}^{-3}$ ) soil; (3) a compacted (bulk density $1.80 \mathrm{Mg} \mathrm{m}^{-3}$ ) soil layer at 100 - to 120 -mm depth with the remaining soil noncompacted (bulk density $1.30 \mathrm{Mg} \mathrm{m}^{-3}$ ); or (4) a compacted (bulk density $1.80 \mathrm{Mg} \mathrm{m}^{-3}$ ) soil layer at 180 - to $200-\mathrm{mm}$ depth with the remaining soil noncompacted (bulk density $1.30 \mathrm{Mg} \mathrm{m}^{-3}$ ). Generally, winter wheat grown in cores that were uniformly compacted or compacted in the upper layer responded similarly. Plant height, at the end of the experiment ( $32 \mathrm{~d}$ after planting), for the uniformly compacted and upper compacted layer treatments was $280 \mathrm{~mm}$, compared to $323 \mathrm{~mm}$ for the control (uniformly noncompacted). Leaf area development was similar to the response indicated for plant height throughout the growth period. Root mass and length tended to be less in layered or compacted soil than in noncompacted soil. Roots accumulated within or immediately above compacted soil layers. Higher bulk density or a shallow compacted layer produced winter wheat with reduced height, leaf area, and dry matter compared with soil of normal density or with a deeper compacted layer.

Key words: Bulk density, Triticum aestivum L., tillage pan, wheat (winter)

[Croissance du blé d'hiver en sol artificiellement compacté.]

Titre abrégé: Croissance du blé en sol compacté.

L'usage inapproprié des instruments agricoles peut entraîner la formation d'une couche de sol dense appelée semelle de labour. Les effets des couches de sol compacté sur la croissance des plantes ont déjà fait l'objet de beaucoup d'études mais ne sont pas encore bien compris. Notre expérience, effectuée en serre, avait pour objectif d'évaluer les effets d'un sol uniformément compacté et de couches minces de sol compacté placées à diverses profondeurs sur le début de la croissance du blé d'hiver (Triticum aestivum L.). Des échantillons de sol artificiellement compacté (loam limoneux Alliance, Argiustoll aridique; horizon A) ont été préparés dans des tubes de chlorure de polyvinyle de $150 \mathrm{~mm}$ de diamètre sur $350 \mathrm{~mm}$ de longueur. Les quatre types de carottes de sol ainsi préparées étaient: (1) sol uniformément meuble (densité apparente de 1,30 $\left.\mathrm{mg}^{-3}\right)$; (2) sol uniformément compacté (densité) apparente de $1,80 \mathrm{mg} \mathrm{m}^{-3}$ ); (3) couche de sol compacté (densité apparente de $1,80 \mathrm{mg} \mathrm{m}^{-3}$ ) entre 100 et $120 \mathrm{~mm}$ de profondeur, le reste du sol n'étant pas compacté (densité apparente de $1,30 \mathrm{mg} \mathrm{m}^{-3}$ ); (4) couche de sol compacté (densité apparente de $1,80 \mathrm{mg} \mathrm{m}^{-3}$ ) entre 180 et $200 \mathrm{~mm}$ de profondeur, le reste du sol n'étant pas compacté (densité apparente de $1,30 \mathrm{mg} \mathrm{m}^{-3}$ ). 
En général, le blé d'hiver a réagi de façon comparable dans les carottes uniformément compactées ou contenant une couche compactée dans leur portion supérieure. La hauteur des plantes, à la fin de l'expérience (32 jours après l'ensemencement), atteignait $280 \mathrm{~mm}$ pour les carottes uniformément compactées ou contenant une couche compactée dans leur portion supérieure, comparativement à $328 \mathrm{~mm}$ pour les plantes du groupe témoin (sol uniformément meuble). La surface foliaire a évolué de façon semblable à la hauteur des plantes pendant toute la durée de la période de croissance. Le poids et la longueur des racines avaient tendance à être moindres dans les sols uniformément ou partiellement compactés. Les racines avaient tendance à s'accumuler dans la couche de sol compacté ou immédiatement au-dessus. La densité apparente plus élevée ou la présence d'une couche compactée près de la surface a donné des plantes de hauteur, de surface foliaire et de teneur en matière sèche réduite comparativement aux sols de densité normale ou contenant une couche compactée plus profonde.

Mots clés: Densité apparente, Triticum aestivum L., semelle de labour

The normal use of tillage tools can create compacted layers (pans) at the tillage depth (McKibben 1971), but the severity of compaction depends on the tillage implement, soil condition at time of tillage, and crop subsequently grown. Tillage pans, which possess vastly different chemical (Kemper et al. 1971) and physical (Raney 1971) properties than bulk soil, may adversely affect growth of roots and shoots (Taylor 1971).

Total root and shoot dry matter of maize (Zea mays L.) and annual ryegrass (Lolium rigidum Gaud.) were only slightly affected by compacted soil layers in a study by Shierlaw and Alston (1984); however, root distribution was altered greatly. Placement of a $100-\mathrm{mm}$ compacted layer 100 or $200 \mathrm{~mm}$ below the soil surface did not significantly influence tillering, total dry matter, or grain yield of well-watered and well-fertilized wheat (Triticum aestivum L.) plants (Tomar et al. 1981). Conversely, Schuurman and de Boer (1974) found that shoot mass of oat (Avena sativa $\mathrm{L}$.) seedlings was nearly identical in the early developmental stages for various treatments of depth and density of topsoil and subsoil. But, in later stages, plants grown in pots with the thinnest layer of loose (bulk density $1.34 \mathrm{Mg} \mathrm{m}^{-3}$ ) topsoil overlaying compacted subsoil (bulk density $1.55 \mathrm{Mg} \mathrm{m}^{-3}$ ) had the greatest shoot mass.

Hemsath and Mazurak (1974) reported that, generally, the rate of root elongation of sorghum (Sorghum bicolor (L.) Moench) seed- lings decreased as soil bulk density increased; however, the greatest root elongation rate was found at a bulk density of $1.50 \mathrm{Mg} \mathrm{m}^{-3}$. They suggested that anchoring of existing root tissue was stronger at this bulk density, which, in turn, allowed the growing root tip to exert more pressure to extend itself. Lowry et al. (1970) also found a negative relationship between plant growth and pan density and depth-to-pan in a field experiment with cotton (Gossypium hirsutum L.).

In previous work (Wilhelm et al. 1982), we studied the effect of fallow tillage practices on root development and growth of winter wheat. Results indicated that soil layers with higher density and strength reduced root density. Dense layers were present in all tillage treatments evaluated, even the treatment which had not been tilled for the previous five crop-fallow cycles. In the same experiment, slightly more grain was produced by the notillage treatment (Fenster and Peterson 1979). The current study was undertaken to evaluate the impact of thin, compacted layers of soil and uniformly compacted soil on early growth and development of winter wheat, which could not be accurately assessed under field conditions.

\section{MATERIALS AND METHODS}

The soil used for this study was the A horizon of an Alliance silt loam (fine-silty, mixed, mesic Aridic Argiustoll, similar to eluviated brown chernozem) from a site approximately $11.2 \mathrm{~km} \mathrm{NNW}$ 
of Sidney, Nebraska, at the University of Nebraska High Plains Agricultural Research Laboratory $\left(41^{\circ} 14^{\prime} \mathrm{N}\right.$ latitude, $103^{\circ} 0^{\prime} \mathrm{W}$ longitude). The soil contained 31,48 , and $21 \%$ sand, silt, and clay, respectively. The soil was air-dried and passed through a 5-mm sieve to remove rocks, concretions, and large pieces of organic material.

Water was added to air-dried soil to generate a series of samples with water contents of $0.04,0.08$, $0.10,0.13,0.14,0.18,0.19$ and $0.23 \mathrm{~kg} \mathrm{~kg}^{-1}$. After these soil samples had equilibrated in sealed plastic bags for $3 \mathrm{~d}$, with twice-daily mixing, the standard compactibility test (Felt 1965) was performed on each in triplicate. Maximum density $(1.80 \mathrm{Mg}$ $\mathrm{m}^{-3}$ ) of this soil was achieved at $0.16 \mathrm{~kg} \mathrm{~kg}^{-1}$ water content (Fig. 1). A density of $1.30 \mathrm{Mg} \mathrm{m}^{-3}$ was achieved at a water content of $0.04 \mathrm{~kg} \mathrm{~kg}^{-1}$.

Appropriate quantities of soil were prepared at these water contents and again allowed to equilibrate in sealed plastic bags for $3 \mathrm{~d}$ with twice-daily mixing. The $300-\mathrm{mm}$ soil cores used in this study were prepared in $150-\mathrm{mm}$ inside diameter by 350- $\mathrm{mm}$ (50-mm headspace) long polyvinyl chloride (PVC) pipe. Treatments were: (1) Uniformly noncompacted (bulk density $1.30 \mathrm{Mg} \mathrm{m}^{-3}$ ) soil; (2) uniformly compacted (bulk density $1.80 \mathrm{Mg}$ $\mathrm{m}^{-3}$ ) soil; (3) a compacted (bulk density $1.80 \mathrm{Mg}$ $\mathrm{m}^{-3}$ ) soil layer at 100 - to $120-\mathrm{mm}$ depth with the remaining soil noncompacted (bulk density 1.30 $\mathrm{Mg} \mathrm{m}^{-3}$ ); or (4) a compacted (bulk density 1.80 $\mathrm{Mg} \mathrm{m}^{-3}$ ) soil layer at 180 - to 200 -mm depth with the remaining soil noncompacted (bulk density 1.30 $\mathrm{Mg} \mathrm{m}^{-3}$ ). Compaction was achieved by the same procedure used for the compactibility test, i.e., 25 blows with a $2.5-\mathrm{kg}$ falling weight. In layered treatments, the compacted layer was prepared first and supported by a wooden plug as the soil for the less dense layers was added and consolidated. For treatments with uniform density, soil was added and compacted in successive 60 -mm layers. In all treatments, the surface of the most recently compacted zone was scratched with a spatula to provide better contact between layers and more uniform consolidation.

After wetting the soil columns by immersing them in water to within $5 \mathrm{~mm}$ of the surface for $2 \mathrm{~d}$ and allowing drainage, four seeds of wheat (Centurk 78) were planted ( $25 \mathrm{~mm}$ ) in each core, and pots were covered with plastic wrap to limit water evaporation during germination. After germination, the plastic wrap was removed, seedlings were thinned to two plants per column, and the cores covered with $25 \mathrm{~mm}$ of ground polystyrene to limit evaporation of soil water during growth of the plants. Cores were watered periodically during the 32- $\mathrm{d}$ experiment to a predetermined weight (field capacity ( $30 \mathrm{kPa}$ ) for each of the soil treatments plus mass of the pot and polystyrene) to insure water was not limiting plant growth. The experiment was conducted in a greenhouse with natural day length $(10 \mathrm{~h})$ and day and night temperatures of 27 and $16^{\circ} \mathrm{C}$, respectively.

Dates of leaf and tiller exsertion were recorded. Rate of tiller production was calculated from the total number of tillers produced during the experiment divided by the duration of the experiment in days (32). The number of days between appearance of successive leaves was recorded and used to calculate the phyllochron of the main stem for each treatment. Leaf area was determined by

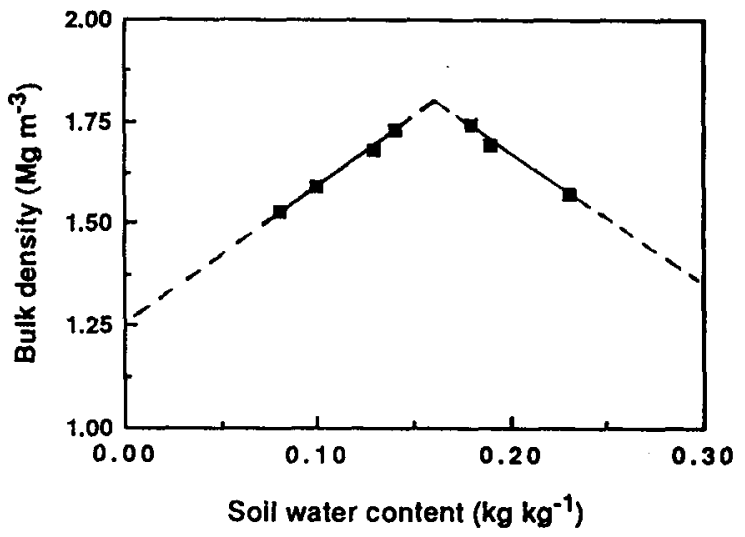

Fig. 1. Relationship between bulk density and water content of Alliance silt loam topsoil. 
summing 0.76 of the product of leaf length and width measurements of each leaf twice each week (Watson et al. 1958). At the end of the experiment, aboveground dry matter was determined by cutting plants at the soil surface and drying at $70^{\circ} \mathrm{C}$ to constant mass. Below ground dry matter was measured with depth in the soil core. The uniformly dense cores were separated into three $100-\mathrm{mm}$ segments. Layered cores were separated into four segments: two $100-\mathrm{mm}$ low-density layers; the $20-\mathrm{mm}$ high-density layer; and the adjacent 80-mm lowdensity layer. Roots were washed from the soil by gentle shaking in water (Ward et al. 1978). Root length was determined by the method described by Wilhelm et al. (1983). Root mass was determined after material was dried at $70^{\circ} \mathrm{C}$ to constant mass. Data were analyzed by analysis of variance; orthogonal contrasts were used to separate treatment means (Steel and Torrie 1960).

\section{RESULTS}

In general, the treatment uniformly compacted to $1.80 \mathrm{Mg} \mathrm{m}^{-3}$ and the upper compacted layer treatment produced similar growth of wheat (Fig. 2). By the end of the experiment, these treatments produced plants about $280 \mathrm{~mm}$ tall compared to $323 \mathrm{~mm}$ for the control (uniformly noncompacted treatment), about a $15 \%$ reduction in plant height. The compaction treatments affected aboveground plant growth more than belowground growth (Tables 1 and 2).

Leaf areas of wheat plants grown in uniformly compacted soil and the soil with the upper compacted layer were similar and smaller than those of the control treatment (Table 1). Leaf area increased at a nearly linear rate during the first $24 \mathrm{~d}$ of growth for all treatments (Fig. 3). The uniformly compacted treatment and the upper compacted layer treatment had somewhat reduced rate of leaf growth compared to the control and lower compacted layer treatments. During the last $6 \mathrm{~d}$ of the experiment, leaf growth rate increased for all treatments, but the rate of increase for the uniformly compacted and upper compacted layer treatment was less than for the control and lower compacted layer treatments. Final leaf areas for wheat from the uniformly compacted, upper compacted layer, and lower compacted layer treatments

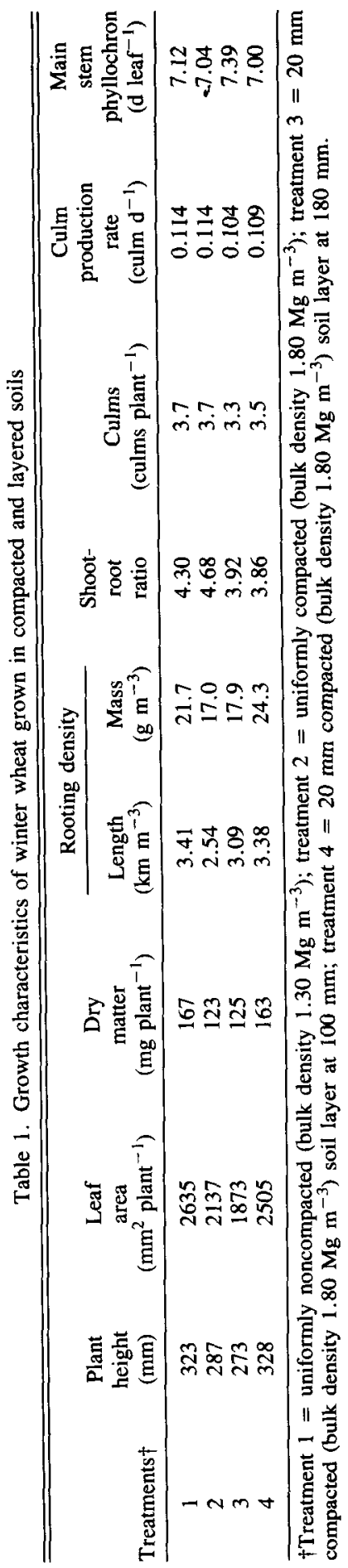




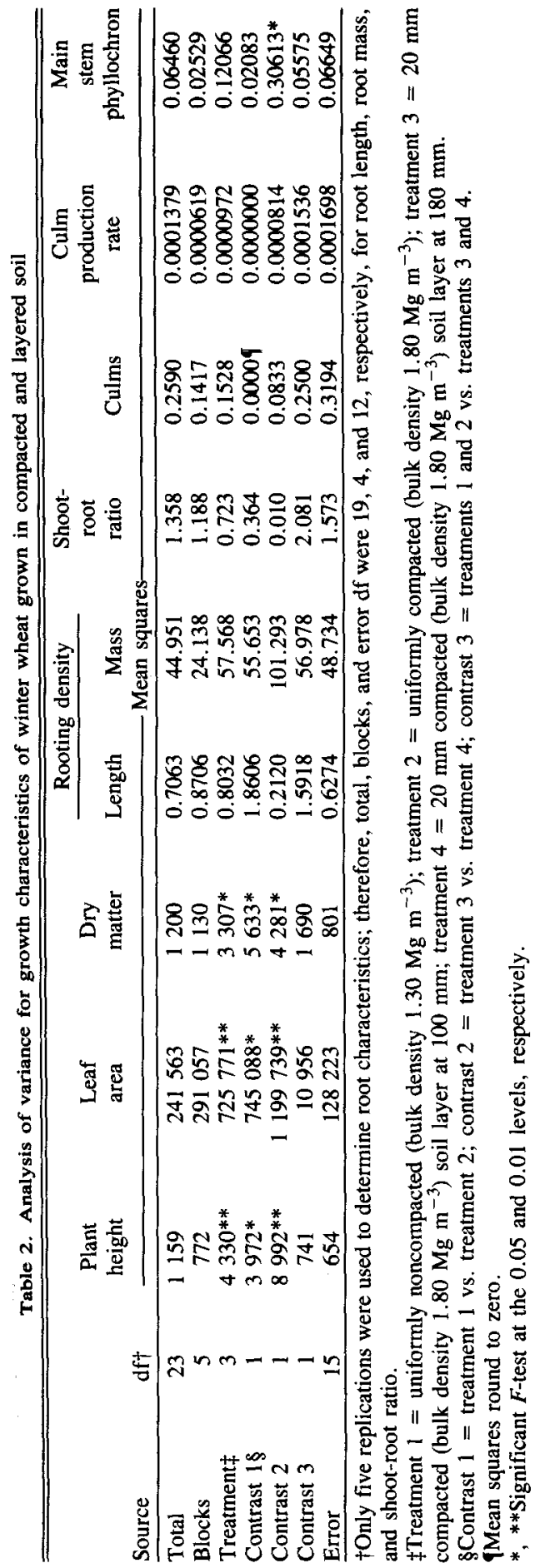

were 81,71 and $95 \%$ of the control treatment, respectively.

Total aboveground dry matter production during the 32-d growth period ranged from $123 \mathrm{mg} \mathrm{plant}^{-1}$ for the uniformly compacted treatment to $167 \mathrm{mg} \mathrm{plant}^{-1}$ for the control (Tables 1 and 2). Treatments with the least volume of compacted soil in the area where the seed was planted produced greatest dry mass.

Although variability in root characteristics resulted in no significant treatment effects $(P>0.05)$, the absolute differences in total root length and total root mass suggested that greater soil bulk density resulted in less extensive root systems (Table 1). The pattern of root development in our study varied with depth in the profiles. Generally, both root mass and length decreased with depth (Fig. 4), with root mass adhering to this generalization more than root length. Root-length data indicated generally less total root material in uniformly compacted soil compared to the other treatments at all depths. Also, an accumulation of roots seemed to occur within or immediately above dense zones in layered soils. This accumulation was more apparent in the root-length data than root-mass data.

Shoot:root ratios (Table 1) did not differ significantly (Table 2) among the treatments. However, the greater ratio for the uniformly compacted treatment may indicate a relatively greater influence of soil bulk density on root growth than shoot growth.

Tiller production rate, although not significant (Table 2), tends to indicate that soil with the upper compacted layer produced culms at a slower rate than the other treatments. Similar results were found for number of culms plant ${ }^{-1}$. All treatments had similar phyllochron of about $7.14 \mathrm{~d}$ (Table 1).

\section{DISCUSSION}

High soil densities can significantly reduce aboveground growth of wheat (Table 2). Taylor et al. (1972) reported similar effects of dense soil pans on aboveground and below ground growth in cotton in a rhizotron. High strength prevented root penetration into the 


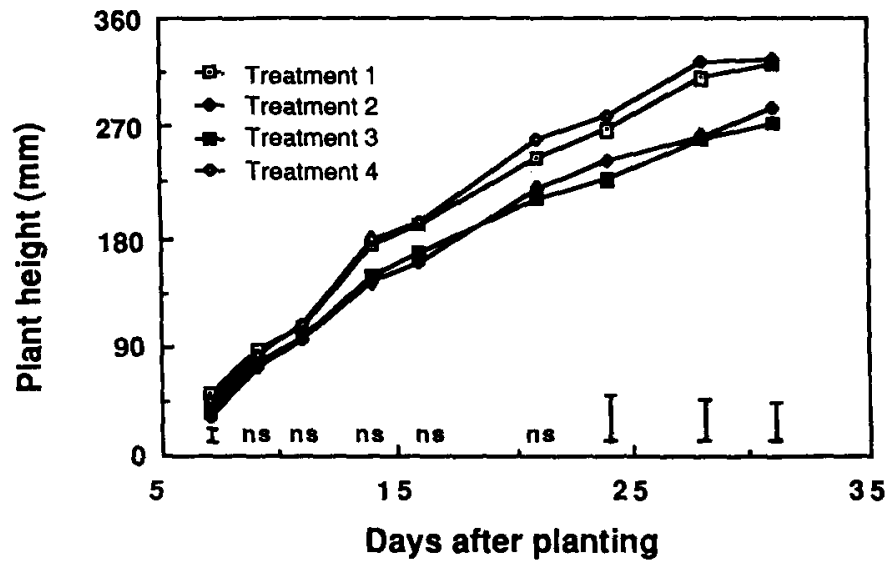

Fig. 2. Height of winter wheat plants grown in four compaction treatments: 1. Uniformly noncompacted (bulk density $1.30 \mathrm{Mg} \mathrm{m}^{-3}$ ) soil. 2. Uniformly compacted (bulk density $1.80 \mathrm{Mg} \mathrm{m}^{-3}$ ) soil. 3. A compacted (bulk density $1.80 \mathrm{Mg} \mathrm{m}^{-3}$ ) soil layer at 100 - to $120-\mathrm{mm}$ depth with the remaining soil noncompacted (bulk density $1.30 \mathrm{Mg} \mathrm{m}^{-3}$ ). Or 4. A compacted (bulk density $1.80 \mathrm{Mg} \mathrm{m}^{-3}$ ) soil layer at 180 - to 200 -mm depth with the remaining soil noncompacted (bulk density $1.30 \mathrm{Mg} \mathrm{m}^{-3}$ ). Error bars represent LSD at $\alpha=0.05$.

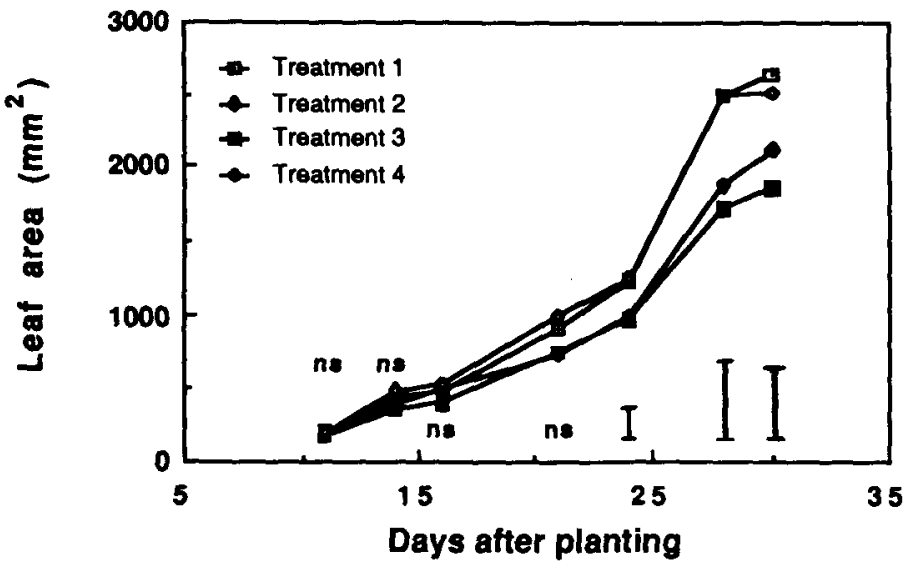

Fig. 3. Leaf area of winter wheat plants grown in four compaction treatments: 1 . Uniformly noncompacted (bulk density $1.30 \mathrm{Mg} \mathrm{m}^{-3}$ ) soil. 2 . Uniformly compacted (bulk density $1.80 \mathrm{Mg} \mathrm{m}^{-3}$ ) soil. 3. A compacted (bulk density $1.80 \mathrm{Mg} \mathrm{m}^{-3}$ ) soil layer at 100 - to $120-\mathrm{mm}$ depth with the remaining soil noncompacted (bulk density $1.30 \mathrm{Mg} \mathrm{m}^{-3}$ ). Or 4 . A compacted (bulk density $1.80 \mathrm{Mg} \mathrm{m}^{-3}$ ) soil layer at 180 - to $200-\mathrm{mm}$ depth with the remaining soil noncompacted (bulk density $1.30 \mathrm{Mg} \mathrm{m}^{-3}$ ). Error bars represent LSD at $\alpha=0.05$.

pan for the first $20 \mathrm{~d}$ of the experiment and reduced plant height and yield. Lowry et al. (1970) reported similar effects of high soil bulk density on field-grown cotton. Although dry-mass production of wheat was reduced by the presence of dense soil, no effect on tiller production was observed. Tomar et al. (1981) also found no effect of dense soil layers on tiller production in wheat.

Positioning of the dense layer also influenced 

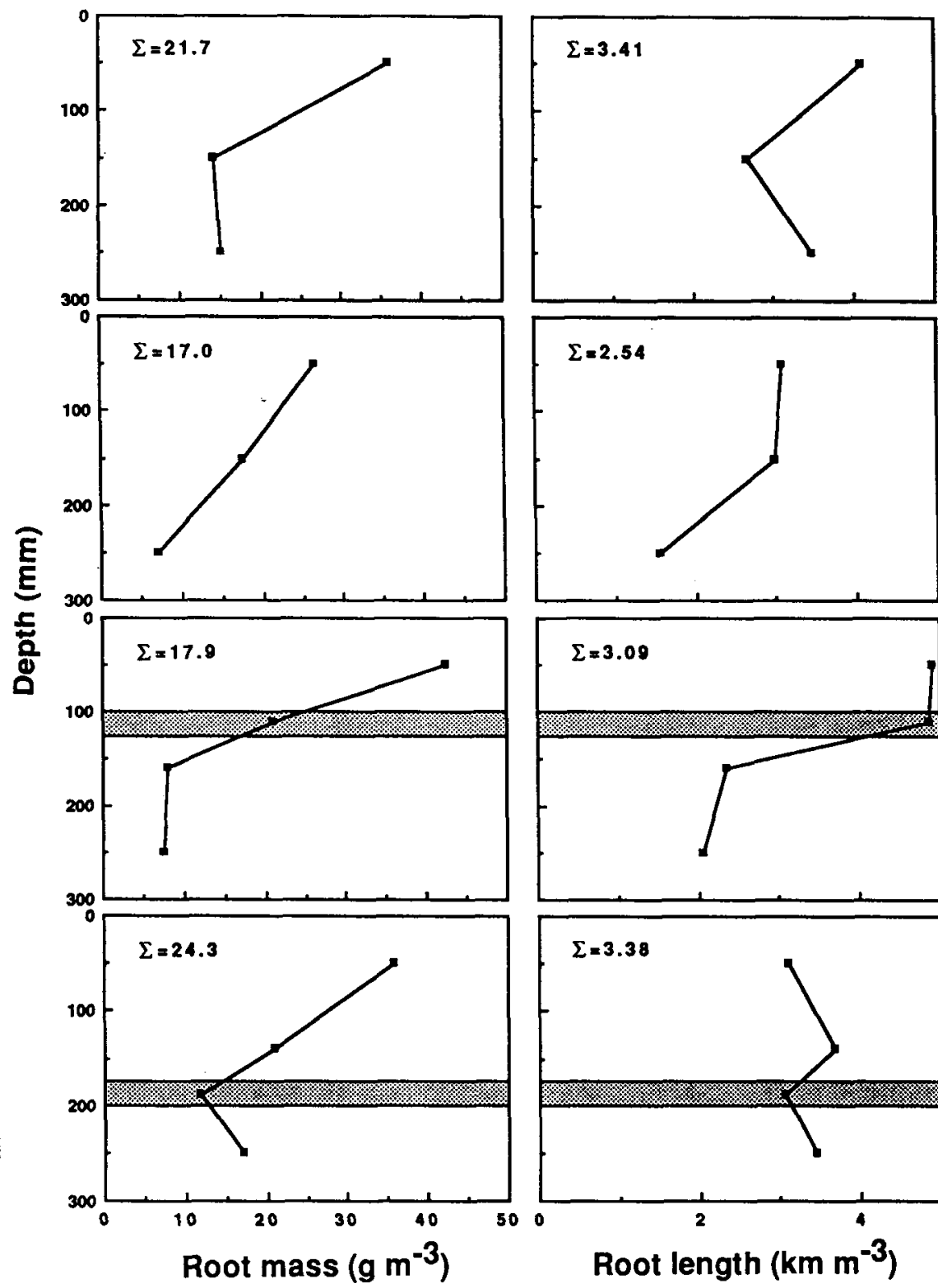

Treatment

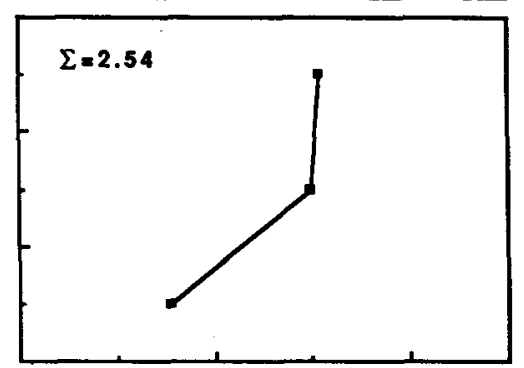

1

2

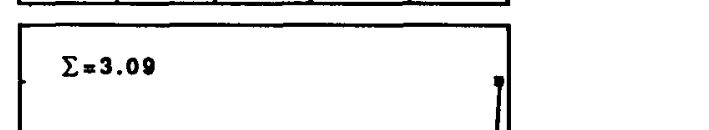

Fig. 4. Root weight and root length of winter wheat grown in four compaction treatments: 1 . Uniformly noncompacted (bulk density $1.30 \mathrm{Mg} \mathrm{m}^{-3}$ ) soil. 2 . Uniformly compacted (bulk density 1.80 $\mathrm{Mg} \mathrm{m}^{-3}$ ) soil. 3. A compacted (bulk density $1.80 \mathrm{Mg} \mathrm{m}^{-3}$ ) soil layer at 100 - to $120-\mathrm{mm}$ depth with the remaining soil noncompacted (bulk density $1.30 \mathrm{Mg} \mathrm{m}^{-3}$ ). Or 4 . A compacted (bulk density 1.80 $\mathrm{Mg} \mathrm{m}^{-3}$ ) soil layer at 180 - to 200 -mm depth with the remaining soil noncompacted (bulk density 1.30 $\left.\mathrm{Mg} \mathrm{m}^{-3}\right) . \Sigma$ represents total root mass or length. Shaded area represents the dense $\left(1.80 \mathrm{Mg} \mathrm{m}^{-3}\right)$ zone in layered treatments. 
growth, with a pan located nearer the soil surface being most detrimental. Dense layers located near the soil surface may be more deleterious to growth than uniformly compacted profiles (Table 2). These results are similar to those of Lowry et al. (1970), who found a greater degree of growth reduction in a treatment with a dense layer placed at a depth of $100 \mathrm{~mm}$ than at 200 or $300 \mathrm{~mm}$. They suggested that limited water availability due to the restricted rooting volume was the primary factor causing reduced growth in the field study; however, limited water availability was not a factor in our controlledenvironment study. In experiments on sorghum seedling growth in soils with a range of bulk densities and water contents (Hemsath and Mazurak 1974), greatest root growth occurred at an intermediate bulk density (1.50 $\mathrm{Mg} \mathrm{m} \mathrm{m}^{-1}$ ). The authors interpreted this to mean that improved anchorage provided by the moderate density enhanced root development.

Results presented here indicate that compacted soil can reduce growth of winter wheat. It appears that the plant perceives the compaction as it would a restricted root volume (Peterson et al. 1984). Although under field conditions the reduced root mass was not associated with grain yield reduction (Wilhelm et al. 1982), this study strongly suggests a reduction in residue production. Under dryland conditions, the yield of grain and residue was directly related to amount of residue from the previous crop applied to the soil surface (Wilhelm et al. 1986). The combined effects of soil compaction and reduced residue production may ultimately contribute to reduced grain yield.

\section{ACKNOWLEDGMENT}

Contribution from the Agricultural Research Service, U.S. Dept. of Agriculture, in cooperation with the Nebr. Agric. Res. Div., University of Nebraska-Lincoln, Lincoln, Nebr. Published as paper no. 8406, Journal Series, Nebr. Agric. Res. Div.

Felt, E. J. 1965. Compactibility. Pages 400-412 in C. A. Black, D. D. Evans, J. L. White, L. E.
Ensmenger, and F. E. Clark, eds. Methods of soil analysis. Part 1. Physical and mineralogical properties, including statistics of measurements and sampling. Agronomy no. 9. Am. Soc. Agron., Madison, Wis.

Fenster, C. R. and Peterson, G. A. 1979. Effects of no-tillage fallow as compared to conventional tillage in a wheat-fallow system. Nebr. Agric. Exp. Sta. Res. Bull. 289.

Hemsath, D. L. and Mazurak, A. P. 1974. Seedling growth of sorghum in clay-sand mixtures at various compactions and water contents. Soil Sci. Soc. Am. Proc. 38: 387-390.

Kemper, W. D., Stewart, B. A. and Porter, L. K. 1971. Compaction as it affects soil conditions: D. Effects of compaction on soil nutrient status. Pages 178-189 in K. K. Barnes, W. M. Carleton, H. M. Taylor, R. I. Throckmorton, and G. E. VanderBerg, eds. Compaction of agricultural soils. Am. Soc. Agric. Eng., St. Joseph, Mich.

Lowry, F. E., Taylor, H. M. and Huck, M. G. 1970. Growth rate and yield of cotton as influenced by depth and bulk density of soil pans. Soil Sci. Soc. Am. Proc. 34: 306-309.

McKibben, E. G. 1971. Introduction. Pages 3-6 in K. K. Barnes, W. M. Carleton, H. M. Taylor, R. I. Throckmorton, and G. E. VanderBerg, eds. Compaction of agricultural soils. Am. Soc. Agric. Eng., St. Joseph, Mich.

Peterson, C. M., Klepper, B., Pumphrey, F. V. and Rickman, R. W. 1984. Restricted rooting decreases tillering and growth of winter wheat. Agron. J. 76: 861-893.

Raney, W. A. 1971. Compaction as it affects soil conditions: E. Summary. Page 125 in K. K. Barnes, W. M. Carleton, H. M. Taylor, R. I. Throckmorton, and G. E. VanderBerg, eds. Compaction of agricultural soils. Am. Soc. Agric. Eng., St. Joseph, Mich.

Schuurman, J. J. and de Boer, J. J. 1974. The effect of soil compaction at various depths on root and shoot growth of oats. Neth. J. Agric. Sci. 22: 133-142.

Shierlaw, J. and Alston, A. M. 1984. Effect of soil compaction on root growth and uptake of phosphorus. Plant Soil 77: 15-28.

Steel, R. G. D. and Torrie, J. H. 1960. Principles and procedures of statistics. McGraw-Hill Book Company, New York.

Taylor, H. M. 1971. Soil conditions as they affect plant establishment, root development and yield: F. Effects of soil strength on seedling emergence, root growth, and crop yield. Pages 292-305 in 
K. K. Barnes, W. M. Carleton, H. M. Taylor, R. I. Throckmorton, and G. E. VanderBerg, eds. Compaction of agricultural soils. Am. Soc. Agric. Eng., St. Joseph, Mich.

Taylor, H. M., Huck, M. G. and Klepper, B. 1972. Root development in relation to soil physical condition. Pages 57-77 in D. Hillel, ed. Optimizing the soil physical environment toward greater crop yield. Academic Press, Inc. New York.

Tomar, S. S., Russell, M. B. and Tomar, A. S. 1981. Effect of subsurface compaction on root distribution and growth of wheat. Z. Acker- Pflanzenbau. 150: 62-70.

Ward, K. J., Klepper, B., Rickman, R. W. and Allmaras, R. R. 1978. Quantitative estimate of living wheat-root lengths in soil cores. Agron. J.
70: 675-677.

Watson, D. J., Thorne, G. N. and French, S. A. W. 1958. Physiological causes of differences in grain yield between varieties of barley. Ann. Bot. (N. S.) 22: 321-352.

Wilhelm, W. W., Doran, J. W. and Power, J. F. 1986. Corn and soybean yield response to crop residue management under no-tillage production systems. Agron. J. 78: 184-189.

Wilhelm, W. W., Mielke, L. N. and Fenster, C. R. 1982. Root development of winter wheat as related to tillage in western Nebraska. Agron. J. 74: 85-88.

Wilhelm, W. W., Norman, J. M. and Newell, R. L. 1983. Semiautomatic X-Y-plotter-based method for measuring root lengths. Agron. J. 75: 149-152. 